\title{
National Identity Expressed in Chinese and Korean Clothing
}

\author{
Chenhao $\operatorname{Sun}^{1} \&$ Jisoo $\mathrm{Ha}^{1}$ \\ ${ }^{1}$ Department of Textiles, Merchandising \& Fashion Design, College of Human Ecology, Seoul National \\ University, Korea \\ Correspondence: Jisoo Ha, Department of Textiles, Merchandising \& Fashion Design, College of Human \\ Ecology, Seoul National University 1 Gwanak-ro, Gwanak-gu, Seoul 08826, Korea. Tel: +82-2-880-1453. \\ E-mail: jisooha@snu.ac.kr
}

Received: January 15, 2020

Accepted: February 5, 2020

Online Published: February 28, 2020

doi:10.5539/ach.v12n1p17

URL: https://doi.org/10.5539/ach.v12n1p17

\begin{abstract}
The purpose of the study is to observe historically national identity expressed in Chinese and Korean Clothing. The literature review and the case study both in China and South Korea were conducted at the same time. The outcomes from the studies are as follow: National identity has been reflected in clothing mainly via the adoption of ethnic elements and civic elements. Chinese and Korean visible-symbolized ethnic elements are from their traditional arts, costumes and lifestyles, invisible-spiritual ethnic elements mainly from religious philosophy. But the Korean wave, which is the modern ethnic invisible-spiritual element, is growing popular all over the world. Chinese and Korean visible-symbolized political elements refer to national or governmental sign, marks or national logo. The invisible-spiritual political elements contain the specific political atmosphere. Chinese are Socialism and anti-capitalism. Meanwhile Korean are Patriotism, Collectiveness, anti-communism and Military ideology. It provides a comprehensive and complete theoretical background for investigating how national identity has been shown in China and Korea's past and current fashion. It is expected to promote the diversified development of both Chinese and Korean clothing design expression in the future.
\end{abstract}

Keywords: National Identity, Civic National Identity, Ethnic National Identity, Chinese Clothing, Korean Clothing

\section{Introduction}

How Chinese or Korean apparel industry ought to be developed, what are the differences between clothing history of two countries, these questions are interested to be explored. China, as an east Asian country of great power that contains 1.4 billion people, brings out a super strong consumption potential that cannot be taken lightly; hence it provides a great foundation for the spread of K-fashion. So more and more Korean apparel industry designers locked Chinese market as the target. China and Korea, as the two main countries of East Asia, have huge differences in the terms of state form and political institutions. For example, Korea is a typical capitalist country whose fashion follows Western countries tightly while China, as a socialist country, keeps its national or ethnic features in fashion to a great extent. It seems very essential and interesting to explore the differences between the two countries from the perspective of national identity (Sun \& Ha, 2019).

Judged by the number of articles published, national identity is a rapidly growing research topic. Sun \& Ha (2019) recently have studied fashion designers' expressions of national identity comparing Korean and Chinese fashion designers but the article compared only the current fashion designers' attitudes without historical perspectives. So this study seeks to help close the gap with a focus on a comparison between the influence of national identity in Chinese and South Korean traditional/non-traditional clothing and also recent modern fashion designers' works. Based on this purpose and vision, two research questions are hereby addressed:

1) What exactly is national identity and how it formed in both China and South Korea respectively?

2) How is national identity shown in Chinese and Korean clothing?

The literature research includes a historic review of both Chinese and Korean national identity, which arrived at the conclusion of definitions and distinctive features of national identity in the two countries. China and Korea are two countries separated by a narrow strip of water and both belonging to the Confucian Culture Circle, so they get many similar culture features. However, from the perspective of the state form, political policy, geographic position, ethnic composition, or social ideology, there does exists huge differences. Hence, the analysis of Chinese 
and Korean national identity is necessary to begin with these historical and social elements. Due to the limited references on this subject, a wide range of information sources such as Chinese, Korean and English books, research papers, internet publications, news clippings, journals, and magazines based on apparel industry, social-science and political field were all reviewed in order to understand the characteristics of national identity and related concepts better.

And analyzing how national identity is shown in clothing conducted into two dimensions, traditional clothing and modern fashion, as case study. For traditional clothing it is from 1948 to 1978 when the true sense of modern fashion has not yet formed in China (Tsui, 2013). The Republic of Korea has been established in 1948 and after $\mathrm{t}$ 1970s democracy has settled in Korean. China has undergone a Socialist Transformation from 1949 to 1970, resulting a situation that individuals were compulsively obedient to the nation. It is no exaggeration to say that during the period there exist no fashion. It is until the opening of the 3rd Plenary Session of the 11th Central Committee of the Communist Party of China that changed the economic situation. In 1980s, the first generation of fashion designers made a figure in China. It was until 1993, the establishment of China Fashion Designers' Association, did fashion designers develop in a vocational way and then from 1998 to 2008, which is an important 10 years for Chinese fashion designers being active in international arena (Kim, 2014). But the first fashion show in Korea was held in 1956, following with the first Fashion Week being held in 1959. Chinese and Korean fashion designers' works after 2000 were viewed intensively. Chinese fashion designers in Shanghai and Beijing fashion week and Korean fashion designers in Seoul fashion week were selected into interpretation.

\section{Definition of National Identity: Civic and Ethnic}

Smith's dichotomous model is one of the classic models of national identity, which contrasts the ethnic-genealogical and civic-territorial models (Smith, 1991). This bi-dimensional framework has always been controversial in the literature, each of two types of national identity is weighted differently across countries (Ha \& Jang, 2015). In other words, both of them coexist to various degrees in all countries and ethnic or civic distinction does not distinguish national identities among countries neatly. Therefore, models were modified by some researchers slightly, a more accurate model than the ethnic-civic division is necessary to be constructed in order to understand the complex national identity better. Hjerm (1998) proposed two other forms of national identity: multiple national identity (both strong ethnic and civic national identity) and pluralist national identity (weak or no sense of national identity) in addition to the ethnic and civic one as Table 1 below.

Table 1. Hjerm (1998)'s Model of National Identity

\begin{tabular}{lcc}
\hline \multirow{2}{*}{ Ethnic } & \multicolumn{2}{c}{ Civic } \\
\cline { 2 - 3 } & Strong Civic National Identity & Weak Civic National Identity \\
\hline Strong Ethnic National Identity & Mixed & Ethnic \\
Weak Ethnic National Identity & Civic & Pluralist \\
\hline
\end{tabular}

Choe (2006), in his comparative study of national identity between China and South Korea, proposed a model of state-centered and ethnic-centered national identity. His article argued that China institutionalized a multi-ethnic, state-centered national identity (the state-centered was later called civic-centered), while South Korea was defined as a single-ethnic, ethnic-centered national identity. Civic or ethnic is just the main attribute but not the only attribute when describe one's national identity.

The research has analyzed Chinese and South Korean national identity based on Smith's 'coexistence' definition, together with Hjerm's notion of national identity. And national identity should be understood as dynamic, fragile and vulnerable (Cillia, Reisigl, \& Wodak, 1999). It still brings in constant renewal in the understanding of its ethnic and civic dimension nowadays. Traditionally, South Korea is a single ethnic country where $98 \%$ of population is ethnic Korean although this information may not comprehensively reflect the increasing population of non-citizen residents. It is obvious that the notion of Korean nation was racialized by underling the myth of a common ancestry. Nevertheless, under the impact of globalization, together with immigration, Korean society has become more multicultural recently, leading to the weakness of ethnic national identity compared to the past. Moreover, the civic type of national identity has grown stronger due to the process of democratization. All these factors help to bring about a mixed national identity in Korea. With China, as a multi-ethnic country, the ethnic national identity has been being closer to civic national identity historically in order to defend unity. Especially in Modern China, the meaning of ethnic in China went through a series of changes from 'each single ethnicity' (such as Han ethnic, minority ethnic) to integrated 'Chinese ethnic' (Zhonghua Minzu). In this vein Chinese ethnic 
national identity describes a sense of identity of both various kinds of ethnicities and Chinese ethnic, and the civic national identity is the link that force the existence and development of China. That is to say, China also generated a mixed type of national identity from the perspective of Chinese history.

The civic dimension of national identity emphasizes the identity that could acquire after birth, such as political rights, duties, values and institutions, political ideology, etc. However, these political rules or ideology established by the government certainly will defend the benefits of the ruling class according to some coercive methods. In this vein the research stands in a dual point of view, on the one hand, discusses what ideology the government quite often initiates and different trends it had in distinctive historical period; on the other hand, depicts how these trends being followed or resisted by individuals. Such an acceptable or resistant progress experienced by citizen could be seen as the formation of civic national identity.

Compared with political identity, the range of civic national identity is limited, especially in territorial and temporal term. In other words, the conception of civic national identity was limited to a period that the nation was established. Taking China and South Korea as examples, theoretically, when discuss these two countries' civic national identity, it should start from 1949 and 1948 respectively.

Ethnic national identity is a notion based on ethnicity, in other words, national identity is driven by ethnic ties-blood, ancestry, nativity, religious, and cultural customs to push the identifying progress to the nation. Ethnic identity is a blood-based concept which is strongly interlinked to its nature of social relations. Cultural identity is the manifestation of individuals' social attributes; hence blood identity appears as cultural identity. It is easier to understand the term ethnic national identity in the cultural perspective than ethnic or racial view when try to interpret it (Meissner, 2006:43). That's why scholars would like to use culture identity or ethnic culture identity more to explain the identity that the individual shows to the ethnic group compared with the term ethnic national identity. However, in this research, ethnic national identity will be adopted instead of ethnic culture identity for the reason that there are nuanced insights between these two terms.

Culture identity refers to the identity or feeling of belonging to, as part of the self-conception and self-perception to ethnicity, religion, social class and any kind of social group that have its own distinct culture (Singh, 2010, p. 86). The distinct culture mentioned here indicates both our culture and other's culture. Therefore, ethnic cultural identity focuses on the identity particularly to original ethnic culture. Moreover, ethnic national identity has a special limitation that it should be built up in individual's nation where he or she was born and grew. As a result, those groups consist of Chinese or Korean overseas are except in the notion of ethnic national identity group. As it were, ethnic national identity is a smaller and more specific conception where this research stands to analyze the relation between ethnic national identity and clothing.

\section{National Identity Expressed in Chinese Clothing}

\subsection{Civic National Identity and Clothing}

In total society, national action is mainly ascribed to the ruling party or state leaders, especially core leadership. These leaders adopt a top-down system arrangement according to issue orders, thereby realize the social control (Sun, 2013). Therefore, it is clear that civic national identity is a conception that tends to political identity, the civic national identity in clothing research is also expected to be analyzed in political perspective. The researcher argues, in clothing field, two dimensions which are visible-symbolized and invisible-spiritual political elements need to be considered in order to understand the civic national identity from a comprehensive perspective.

Visible-symbolized political elements contain signs, marks or logo that could represent a nation, the government, and parties, such as national flag, national emblem, party flag, and party emblem. These symbols are full of strong political meaning, which are hence the representative elements of civic national identity. The most representative political sign, mark and logo in China are the five-star red flag, Chinese emblem, and the communist party flag. These elements mainly showed in clothing such as the style of military uniform. According to the military history of China, Chinese military uniform (Figure 1) had a strong features of socialism period from 1949 to 1978, which was depicted as "wearing a red star on the head and hanging the revolutionary flags in two sides".

During 1949 to 1978, the president Mao Zedong was frequently dressed in reformed Sun Yatsen suit in public occasion hereby it was then called 'Mao's suit' (Figure 2) by western media. Hence, civic national identity needs to be seen from the government view. National enforced dress in different historical periods affected by political ideologues and institutions. These clothes are the outcome of military and political thereby are full of strong political features, which also reflect the civic national identity directly in particular time in the history. Clothing style represents a national identity or the role as a national member (Kim, Cha, \& Lee, 2017). 
During 1949 to 1970, a series of political and economic reforms along with the material deprivation changed the way of people's life and ideology, what people are dressed in was given intensive and forceful political meaning. The government considered that garments reflect personal value system directly and fashion which came from people's ideology which can be controlled by the government as well. Under a social context that everything is ought to keep up with the Soviet Union, as a consequence, the Lenin coat (Figure 3), full of Soviet socialism revolutionary taste, wore by Lenin around the October Revolution, became the new business wear among female. In the age of Culture Revolution Period (1966-1976), fashion seems to encounter unprecedented difficulty than ever (Kunz, 1996). With the slogan of "whatever has been advocated by the enemies (capitalism) ought to be discarded". At that point, fashion items such as dress, skirt, suits, ties, jewelry, perfume, and high-heels, as the result of capitalism, were no except as a matter of course, most of people were dressed in Red Guard style (items such as long sleeve military uniform, green long pants, army cap) together with a canvas bag, becoming the fashion in that period. Being dressed in Red Guard style (Figure 4) also means supporting socialism and be against capitalism and feudalism (Kunz, 1996). Under the trend of collectivism in the early 1970s, the quest for material wealth equals to being against socialism. Hence, China was depicted as a state being filled with blue ants by foreign news (Sun, 2013) because everyone is dressed in monochromatic blue or grey garments without bright and vivid color, even on some festive occasions. That is to say, wearing simply and frugally is the expression of civic national identity. After the Culture Revolution, the government launched the economic reform of 1978 to be China's second revolution in order to invigorate the nation's economy. The economic reform ultimately aimed at modernizing the country and constantly keeping up with the living standards in those western developed countries (e.g. Tyler, 1997). The government encouraged individuals to change their daily apparel because clothing should represent the spirit of the time. It is also in this period that Pierre Cardin was invited to China, indicating that China showed a more open attitude in communicating with western culture and technology. Since then, with a 30-year-frustration, fashion finally began to return back to people's daily life gradually.

Specific Chinese political elements such as national flags and national emblems, as holy symbols in China, are subtle to some extent. As stipulated by the Chinese Flag Law, it is forbidden to humiliate national flags by means of burning, destroying, painting, defiling, trampling in public places as well as be used in commercial advertising or as commercial logo. Therefore, only in some special national occasions, for example, the Olympic Games, can we see these type of political elements. It is easy to get the blame if it was designed in a wrong way. For example, in the use of Chinese Flag element of fashion design (Figure 5), the girl was shoot in the Cannes Film Festival and then being criticized by Chinese public on the internet. For all Chinese people, Chinese flag is also a symbol of Chinese dignity, hence everyone is ought to show respect to the national flag. However, the girl is a little bit sensationalistic in Chinese people's view. But on the other hand, the adoption of some other political elements are flexible. Seeing those who wear garments with political symbols, for example, CCP flags, as the determined supporter of CCP is unreasonable.

The invisible-spiritual political elements refer to the conception that clothing itself has no political complexion, but under the impact of the external atmosphere such as political ideology, national policy or political orientation does clothing reflect political features. The clothing has particular meaning attached to it due to the T.P.O (Time, Place and Occasion). It is the political nature of the international conference or state visiting itself that helped the political atmosphere in clothes, which is known as political fashion. The strong political meaning is prepared only for politician or not general public, therefore, civic national identity in this section is ought to be understood in the dimension of the government. Chinese first lady Peng Liyuan (Figure 6) showed her political debut with Chinese president Xi Jinpin in 2013 and her fashion style and good sense leaded to a heated discussion in both Chinese and western media. It could even say that she is the first female who highlights the influence of fashion via the political arena (Tsui, 2013). Figure 4 is in 2015 when she accompanied with Xi Jinpin visiting England. The president wore a set of traditional Chinese Sun Yatsen suit, while she was dressed in deep blue custom-tailored dress which combines Chinese ethnic collar and western tailor. A white thin belt girdles her, giving the viewers a refresh impression. 


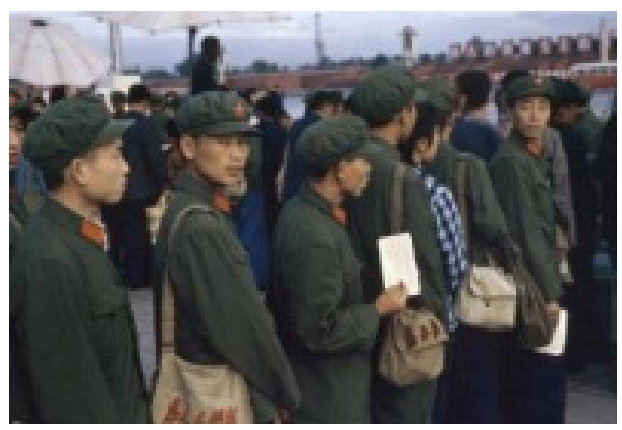

Figure 1. Chinese Military Uniform Source:

https://xw.qq.com/cmsid/20190615A0COUG

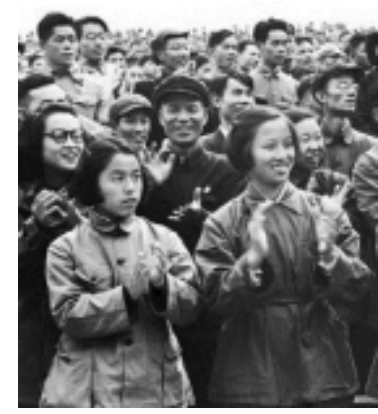

Figure 2. Mao's suit Source:

https://shanghaiist.com/2015/12/ 11/a_century_in_chinese_wome ns_fashion/

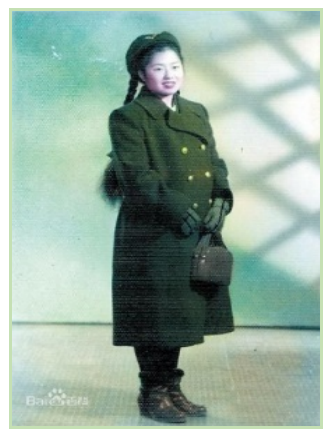

Figure 3. Lenin coat Source:

http://kr.people.com.cn/20309

0/203281/8618386.html

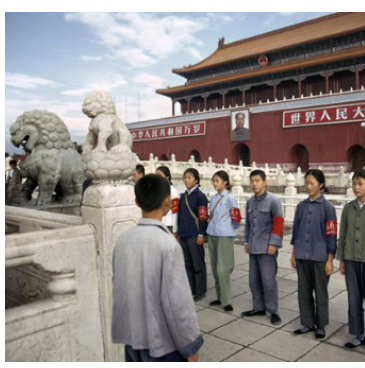

Figure 4. Red Guard Style

Source:

http://blog.naver.com/ PostView.nhn?blogId=china $\operatorname{lab} \& \log \mathrm{No}=221142070693$

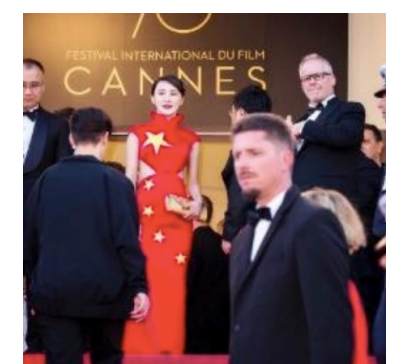

Figure 5. Use of Chinese Flag element of fashion design

Source:

http://blog.naver.com/

PostView.nhn?blogId=nihaozhongguo\& $\log \mathrm{No}=221009837689$ \&parentCategory $\mathrm{N}$

$\mathrm{o}=\&$ category $\mathrm{No}=76 \&$ viewDate $=\&$ is Sho wPopularPosts $=$ true $\&$ from $=$ search

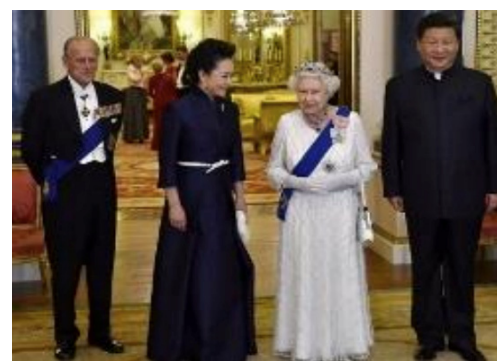

Figure 6. Chinese first lady Peng Liyuan

Source:

https://www.dailymail.co.uk/

femail/article-3280964/Is-Chinese-lady-real-star -state-visit-Peng-Liyuan-

xudes-elegance-cool-white-dress-suit-accompani es-President-Xi-Jinping-Buckingham-Palace.ht $\mathrm{ml}$

\subsection{Ethnic National Identity and Clothing}

As aforementioned before, many scholars explain or interpret ethnic national identity from a historical-cultural perspective. Ethnic culture, as the cohesion force of a nation, plays a role of cornerstone of national identity. The rise of China will be realized via the rise of Chinese culture (Du Weiming, 2012), especially the traditional culture, which is usually be seen as the key to establish national identity (Meng, 2014). The relation between national identity and fashion from two dimensions: visible-symbolized elements, and invisible-spiritual ethnic elements would be looked into.

According to the literature review based on the books, especially『Sings of China $\rrbracket($ Dututime, 2012) Chinese ethnic culture elements which could reflect ethnic national identity and could be used in clothing are divided into three dimensions, which are traditional ethnic arts, traditional costumes and traditional lifestyle. Traditional art has been identified as related to aesthetic which keeps developing in the historical changes. The arts contain traditional handcrafts, operas, paintings, calligraphies, and Chinese Kungfu. These elements are reflected in clothing as embroidery decorations of Chinese opera costumes or Chinese Kungfu clothing. Chinese traditional ethnic clothing contains garments of both Han ethnicity (Figure 7) and ethnic minorities (Figure 8), which appear different features with each other due to the distinctiveness of territory and lifestyle. Traditional clothing of Han ethnicity, known as Hanfu, was rudimentarily formed in the era of the Han dynasty and had no fundamental changes except some details. In modern times, Qipao (Figure 9) became the traditional garments of Chinese female. The definition of Qipao, referring to garments appeared in Republic of China or containing the qizhuang in Qing dynasty or not, is still controversial in the academia of China. Except the clothing culture aforementioned 
above, eating, housing and moving culture also can be shown on Chinese clothing and have impact on dressing tendency. Food culture, traditional architectures, and ethnic festivals also do. For example, in traditional Chinese Spring festival, red is a symbol of bless and lucky, which helps to bring out a red tendency in clothing.

Invisible-spiritual ethnic elements are mainly based on the essential religious belief of one nation or ethnicity, which is a feeling that reflects the core of the religious philosophy. For example, in the oriental philosophy, the beauty of restraint and nature in Taoism, the beauty of simplicity and hideaway in Buddhism and the beauty of order and moderation in Confucianism (Seo \& Kim, 2008). These elements or features are all derived from religious philosophy, the understanding and application of which does embody the ethnic national identity. In the expression of clothing, the three religions are different from each other but the similar features cannot be covered up. Unconstructed forms, restraint color and natural materials, characteristics of oriental religious philosophy could be concluded as hiddenness, simplicity, cleanliness and non-structure (Seo \& Kim, 2008) (Figure 10).

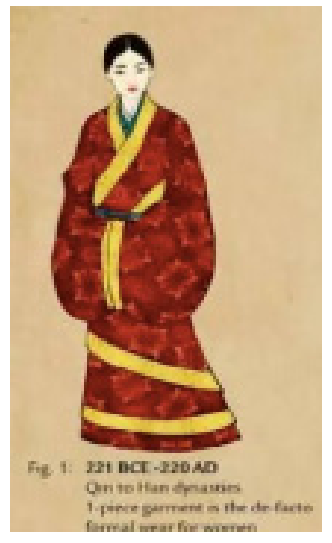

Figure 7. Han Ethnic

Source:

https://medium.com/@ancai/why-i-wont-wear-hanfu-d1ad9d2 $90 \mathrm{e} 1 \mathrm{e}$

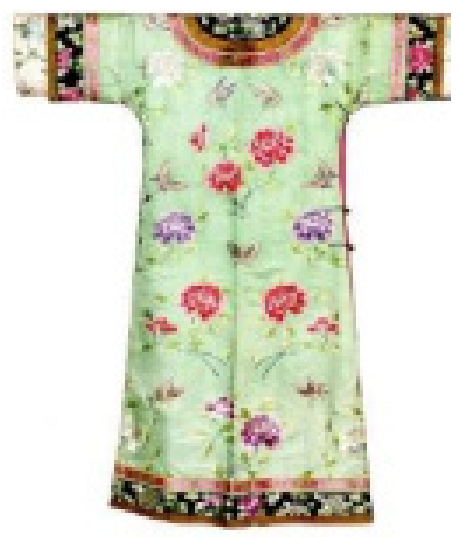

Figure 9. Qipao

Source:

https://kknews.cc/zh-sg/history/3bn469g.html

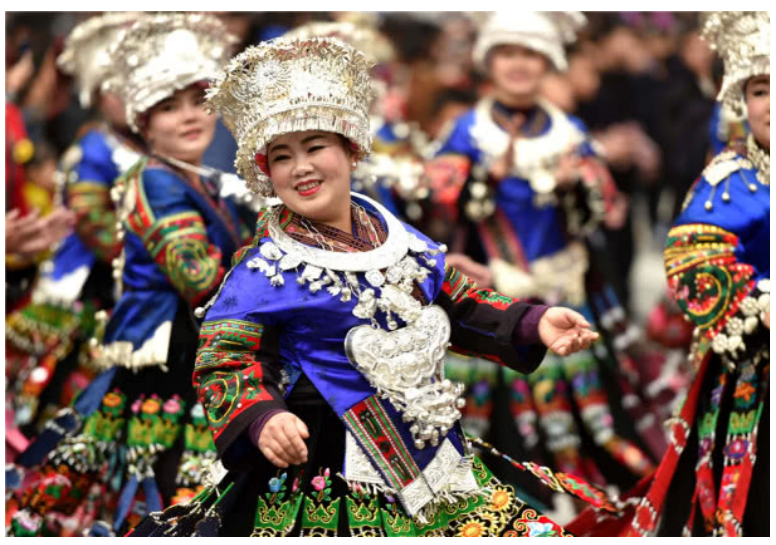

Figure 8. Ethnic Minority

Source:

https://new.qq.com/omn/20171204/20171204A0VIOB.htm 1

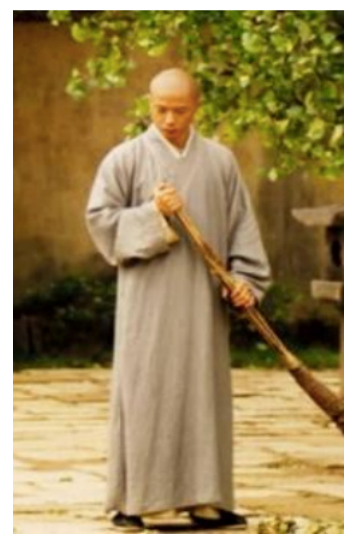

Figure 10. Religious Clothing

Source:

http://baijiahao.baidu.com/s?id=1630237313162853017

There are thousands of fashion designers have attempted to make the connection between visible-symbolized ethnic elements and fashion come true. In Guo Pei's 2016 Spring/Sumer Paris Haute Couture Fashion Show, she improved the continuously-adopted technic named the Palace "Panjin" embroidery so that the Palace Embroidery could be alive and stepped on the international stage. In the past several seasons, Mukzin is a very popular brand in Shanghai Fashion Week due to adopting typical traditional Chinese culture. From traditional 
novels to painting, her collection can be seen as a concentrator of Chinese traditional culture. Culture of ethnic minority groups were also applied by this brand frequently as well. For example, traditional Manchu Han Imperial Feast in ancient China was focused on during the launching of $2017 \mathrm{Spring} / \mathrm{Summer}$ collection named "Food Republic of Man-chu and Han" (Man Han Da Shi Dai).

Exception, as one of the first batch of Chinese designer brands, was founded based on Chinese aesthetic philosophy. In the recent runway show titled "The distant information", traditional crafts from Chinese Miao ethnicity was used in order to bring the natural, plain and diligent oriental life wisdom to the modern life and the daily clothing. Pleats, cotton and linen material and black color, all of these details reveal a calm and easy atmosphere. The garment enfolded the body without any superfluous accessories, which is also related to Buddhist philosophy thought and to Chinese Taoism philosophy: unity of the nature and humanity.

\section{National Identity Expressed in Korean Clothing}

\subsection{Civic National Identity and Clothing}

Similarly, with China as mentioned before, the most representative political sign, mark and logo in South Korea are National Flag, Taegukgi and National Flower, Mugunghwa, which could be seen as symbols of civic national identity. These elements mainly showed in clothing as the style of military uniform. The only obvious difference between Chinese and Korean military uniform is that Korean military was only worn by soldiers or in particular groups but it was by most people in China during the specific historical period.

Invisible-spiritual political elements showed in two categories. First is the feeling of specific political atmosphere, such as in the occasion or forum hold by the government. Since Korea has been getting influential based on successful capitalism, what the national leaders wear is not a different style like what China did like Mao's suit, that is to say western suits were chosen by all male presidents in Korea. Second is national enforced dress in different historical periods affected by political ideologies and institutions, such as Korean military uniform, high school drill uniform in military control period.

These clothes or fashion styles are the outcome of the military and political, which thereby are full of strong political features and could reflect the civic national identity directly in particular time in the history. In the late 1950s, the government began to promote to save resource and clean up corruption, thus clothing life was tied closely with government's policies and guidelines (Kim, 2014). Only through unifying clothing and being dressed in uniforms diligence and thrift could be realized. In the end of 1960s, in order to prevent the sneak attack from North Korean Army, the president Park Chunghee began to establish the national reserve forces and strengthened the military training education targeting to high school students. Those boys in high school who are taking military training courses are required to be dressed in unified drill form (Figure 11). In 1970s fashion did not exist yet in the strict sense because the government still control the clothing. Miniskirt and long hair were forbidden by government. The civic national identity that showed in Korean fashion is a progress of democratization under the foundation of modern democratic government. Before the success of democratization, Korea was in a long-term dictatorship period; citizens had to follow the government's rules, ideologies or institutions without independent options. That is the reason behind clothing-unification (Figure 12); clothing was full of political intentions during this period.

Currently in the globalized world, the restraining force that the politic has to clothing has become weaker and weaker, and clothing has been generalized into the expression of an individual's personality. Designers adopt these political elements in their design without political intention but only to create the new design or express their views to social problems. Although there is also National Flag Laws in Korea, the citizens seem less sensitive and more tolerant to those designs adopting national flags elements. On the whole, Korean civic national identity is more tolerant and less subtle than the Chinese one.

Recently D-antidote is also a popular brand that is famous for combining classic and punky elements of London with cross over trend of Seoul. In its' 2016 Fall/Winter collection, the application of Korean national flag with English characters written as "Seoul/London" was very interesting. This brand was inspired from the designer's experience in both England and Korea, and the adoption of Korean national flag elements can be seen an obvious expression of his Korean civic national identity (Figure 13).

The $<$ Mutual Defense Treaty between the United States and the Republic of Korea $>$, formally signed in Washington in 1953 for indefinite period, is the alliance treaty between America and South Korea. Along with the compulsory military service, Korea result in a strong military attribute in civic national identity. As a result, when designer express civic national identity, a potential military influence has been often shown on nowadays fashion. The application of military elements may be just because of the designer's personal preference or due to the direct impact of civic national identity. Nevertheless, one thing is certain: the military elements, which can be seen as a 
typical symbol of civic national identity, has been applied by a group of Korean designers and have formed an important feature cannot be ignored in Korean.

It is the political nature of the international conference or state visiting itself giving the political attributes to clothes. These politicians, as the main participators of the conference, wear these clothes for political requirement, while general public does not need to. That is why civic national identity ought to be understood in the view of the government in this section. Figure 14 was from the APEC conference held in Seoul, 2005. Clothing worn by leaders was the Korean traditional Hanbok made of totally Korean native silk fabrics. Pine trees and bamboo representing loyalty, nobleness and wise was adopted in the design. The selection of Korean political color blue together with the traditional Hanbok are examples of how Korean civic national identity was showed via the adoption of ethnic elements as well.

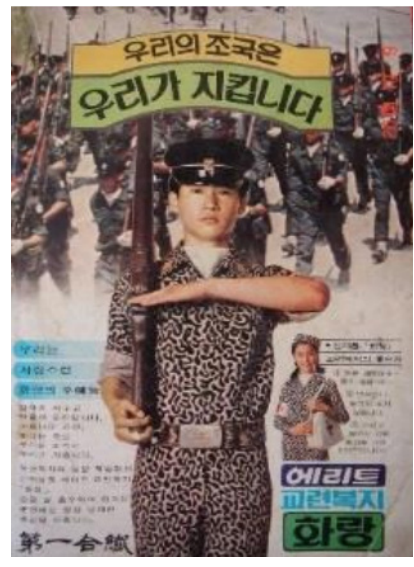

Figure 11. Drill Uniform

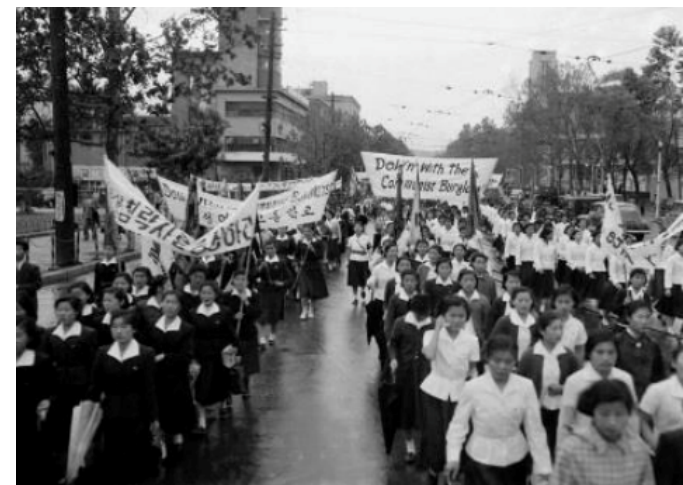

Figure 12. School Uniform
Source:

http://blog.daum.net/sn7777/274

Source:

http://www.khantoday.com/news/service/article/mess 01.asp?P_Index $=8635 \&$ flag $=$

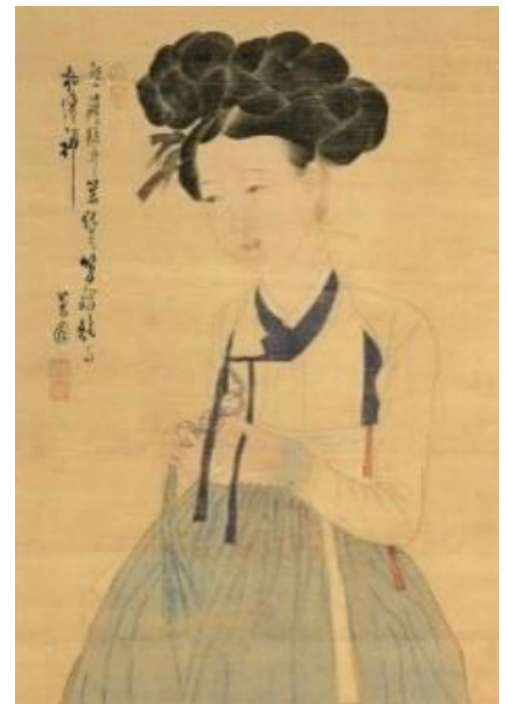

Figure 15. Hanbok

Source:

http://www.mediatoday.co.kr/news/arti cleView.html?idxno=73719

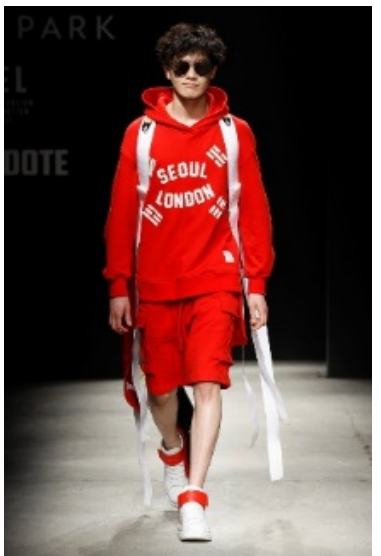

Figure 13. D-Antidote 2016 F/W Source:

https://stylekorea.tumblr.com/ima ge/150029984389

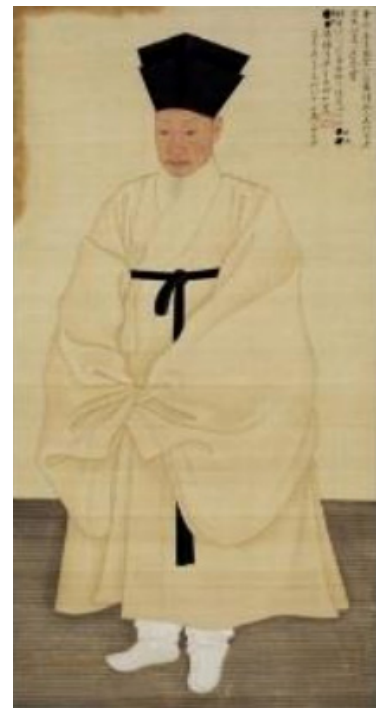

Figure 16. Religious Clothing Source:

http://www.newsquest.co.kr/news/artic leView.html?idxno=72831

\subsection{Ethnic National Identity and Clothing}


The contents of Korean visible-symbolized ethnic elements were analyzed in the same vein with Chinese case. Based on the book Images of Korea Culture (The National Folks Museum of Korea, 2001) ethnic culture elements which reflect ethnic national identity could be divided into three dimensions: Firstly, they are traditional ethnic arts, containing traditional handcrafts, Talchum, Korean paintings, calligraphies, taekwondo and so on. Secondly, historically, Korea has been a single-ethnic country nevertheless the forms of Korean ethnic Hanbok does continue to be so. Although different changes appeared in Hanbok in distinctive dynasty, the basic form or silhouette never changed too much from the ethnic perspective. Hereby, Hanbok in Joseon dynasty, the most recent traditional period, was selected as an example in Figure 15. Thirdly, except the clothing culture aforementioned above, eating, housing and moving culture also can be shown on Korean clothing and have impact on dressing tendency. These elements are food culture, traditional architectures, and ethnic festivals. Similar with China, these elements have slight influence to traditional clothing.

Since China and South Korea both belong to Confucian Culture Circle, there are some shared spiritual ethnic culture. In ancient period, South Korea was mainly affected by China culturally (Kim, 2016). Kim (2016) argues that South Korea has the similar invisible-spiritual ethnic elements with China. The feeling both of the two countries pursing in the context of ethnic national identity is: freedom and peace in spiritual; blank, simple and plain in aesthetics (Figure 16).

Similar with China, there are many fashion designers who adopt ethnic traditional elements in their design. Whether they really attempted to express the ethnic national identity via the application of traditional elements can only be clarified according to the deep interview with designers. Nevertheless, it is certain that the consistent use of ethnic culture elements is important in strengthening the national identity. Many Korean modern fashion designers are adapting various Korean traditional Hanbok elements such as Korean five colors, patchwork quilt technic for their collections. The combination of tradition costume and modern fashion helped to bring out the exotic Korean beauty and was full of dynamic features. Korean fashion designers have evolved from the use of visible-symbolized ethnic elements to invisible-spiritual one, that is to say, the ethnic culture is hidden behind or contained in the garment itself. The motif of 2008 Spring/ Summer collection launched by designer Lee Younghee was "Temple", which directly brings a strong image of oriental religion. The neutral colors and the contrast between the transparent and translucent Hanbok fabrics which manifested the disappeared time, as well as the alternant black and white colors, gives people an intense sense of religious peace and quietness.

When referring to Chinese ethnic culture, traditional ethnic culture seems to be mentioned more, but when it comes to Korean ethnic culture, unlike the Chinese case, most of foreigners will talk about Korean wave that contains pop music, soap operas and movies, in addition to Korean traditional culture. In modern times, Korea has been influenced by Japanese colonial culture, and then American cultures, even European culture, to a lesser degree. Therefore, precisely speaking, the Korean wave could be explained as the Korean culture that was not derived from traditional culture but a hybrid notion that is a mixture of various foreign cultures with a core of Korean spirit (Kim, 2016, p. 113). The Korean wave, from its restricted sense, does not look like following the Korean ethnic but clearly it has been born from the history and ancestry of Korean ethnic. However, the significance of Korean wave is very meaningful historically because never in the history of Korea has our culture been so widely accepted in foreign countries.

Korean wave, referring to Korean idol, music, soap drama, could be seen as carriers of Korean fashion: K-pop idols' fashion style, hairstyle and make-up is being spread worldwide via social network (Byeol \& Geum, 2016).

\section{Conclusions \& Discussion}

In the recent globalized world, with the deeper and wider communication among different countries, it is an irreversible trend that a broader regional features of national identity is emphasized by both Chinese and Korean clothing. This research provides a comprehensive and complete theoretical background for investigating how national identity has been shown in China and Korea's past and current clothing.

The results of this research are as follows:

Firstly, critical visible-symbolized political elements for Chinese national identity are five-star red flag, Chinese emblem, the communist party flag while for Korean national identity R.O.K. flag, Taegukgi and National Flower, Mugunghwa. And Socialism and Anti-capitalism are very essential to Chinese invisible-spiritual political identity while Patriotism, Collectiveness, anti-communism and Military ideology to Korean invisible-spiritual political identity. For Korean civic national identity military influence due to Korean political history and Hanbok should gain attention. Korea is a rare nation which is using traditional costume with strong political message.

Secondly, the key elements for Chinese visible-symbolized ethnic are Chinese silk and embroidery, Chinese 
operas, Chinese Kungfu, Hanfu, qizhuang, Chinese food, and Chinese traditional architectures. For Korean they are Korean traditional handicrafts, Talchum, taekwondo, Hanbok, Korean food culture, Han-ok. And Confucianism, Buddhism, Taoism and Fengshui are essential to Chinese invisible-spiritual ethnic nationality while Confucianism, Buddhism, and white ethnicity as well as the Korean wave, which is the modern ethnic invisible-spiritual element that is growing popularity all over the world, to Korean. The Korean wave influenced fashion are mixed modern style with street touches, forming the Korean unique style. Even though Korean popular culture is not derived from Korean tradition originally and is the mixture of other cultures, worldly-spread Korean wave has Korean spirit at the core. And knowing what Korean spirit is then the key to understand how ethnic national identity carrying in fashion style.

Designers' expression of ethnic national identity nowadays is not as obvious as what the first generation designers did. New designers have evolved from the use of visible-symbolized ethnic elements to invisible-spiritual ones, that is to say the ethnic culture is hidden behind or contained in the garment itself. The invisible-spiritual culture was included in designer's work via the designer's creation. And in most cases, the invisible-spiritual culture was combined with physical objects or symbols closely. That's why even without obvious symbols on the fabrics, a strong or intensive peace, calm and harmony could be felt in one piece of design work. Even though the designers use strongly visible-symbolized political elements, it is for the expression of their political tendency but for the pursuit of newness without political meaning. For understanding style regarding nationality, political and cultural history should be deeply studied as well as the target market and lifestyle analyzed.

The research provides a comprehensive theoretical background for investigating how national identity has been shown in China and Korea's past and current fashion. The supplement to the blank area in previous research is expected to promote the diversified development of both Chinese and Korean fashion designers' design expression in the future. After all, it is not easy to understand national identity itself and the expressions related to it as national identity is built and changed along with the passage of time and history. This study is a mere step, and hopefully ongoing efforts and the exploration to understand a nation, national identity and its expressions will complete the journey in more depth.

On the whole, there are no right or wrong answers in the process of analyzing the relation between national identity and clothing. The most reasonable attitude to this relation is seeking out the identity of designer self-based on the comprehensive understanding of national identity. As it were, the understanding of national identity is more than one nation's thing but syntheses that contains a comprehensive cognition to this global village nowadays. It is firmly believed that Chinese and Korean clothing would gain more international recognition in the near feature.

\section{Acknowledgments}

Funded by BK 21 Plus project of the National Research Foundation of Korea Grant by the Korean Government.

\section{Conflict of interests}

The authors declare that there is no conflict of interests regarding the publication of this paper.

\section{References}

Byeol, A., \& Geum, K. S. (2016). A study on the situation and perspective of K-fashion. Bulletin of Korean Society of Basic Design \& Art, 17(1), 350-362.

Choe, H. (2006). National identity and citizenship in the People's Republic of China and the Republic of Korea. Journal of Historical Sociology, 19(1), 84-118.

Cillia, R. D., Reisigl, M., \& Wodak, R. (1999). The discursive construction of national identities. Discourse \& Society, 10(2), 149-173.

Du, W. M. (2012). Du Weiming: Zhong Guo De Jue Qi Xu Yao Wen Hua De Zhi Cheng. Zhong Dao Wang. Retrieved from http://www.zhongdaonet.com/Newsinfo.aspx?id=362

Dututime. (2012). Signs of China: China Traditional Culture Concise Illustrated Handbook. Hunan: Hunan Fine Arts Publishing House.

Ha, S. E., \& Jang, S. J. (2015). National identity, national pride, and happiness: The case study of South Korea. Social Indicators Research, 121(2), 471-482.

Hjerm, M. (1998). National identity: A comparison of Sweden, Germany and Australia. Journal of Ethnic and Migration Studies, 24(3), 451-469. 
Kim, I. K., Cha, Y. M., \& Lee, J. A. (2017). A comparative study of Korean fashion and K-fashion in 1980s 2010s. Korea Society for Science of Eastern Art, 34, 179-202.

Kim, J. S. (2016). Success without design: Korean wave and its implications for cultural policy. The Korean Journal of Policy Studies, 31(3), 101-118.

Kim, S. M. (2014). A comparative study of external factors for Korean and Chinese fashion designer brand development. A Dissertation for Master Degree. Donghua University.

Kunz, J. L. (1996). From Maoism to Elle: The impact of political ideology on fashion trends in China. International Sociology, 11(3), 317-335.

Meissner, W. (2006). China's search for cultural and national identity from the nineteenth century to the present. China Perspectives, 68, 41-54.

Meng, H. H. (2014). China's national identity in transition: Domestic and international perspectives (1982-2012). Social Sciences in China, 35(2), 189-207.

Patrick, E. T. (1997). Deng Xiaoping: A political wizard who put China on the capitalist road. The New York Times. Retrieved from http://www.nytimes.com/1997/02/20/world/deng-xiaoping-a-political-wizard-who-put -china-on-thecapitalist-road.html

Seo, B. H., \& Kim, M. J. (2008). A study on East Asian costume beauty, affected by religion: Focusing on Buddhism, Taoism, and Confucianism. Journal of the Korean Society of Costume, 58(2), 93-106.

Singh, C. L. (2010). New media and cultural identity. China Media Research, 6(1), 81-84.

Smith, A. D. (1991). National Identity. Reno: University of Nevada Press.

Sun, C., \& Ha, J. (2019). Fashion Designers and National Identity: A Comparative Empirical Analysis of Chinese and Korean Fashion Designers. Asian Culture and History, 11(2), 183-194.

Sun, P. D. (2013). Shi Shang Yu Zheng Zhi: Guang Dong Min Zhong Ri Chang Zhuo Zhuang Shi Shang (1966-1976) (时尚与政治: 广东民众日常着装时尚). A Dissertation for Doctor Degree. Fudan University.

The national folk museum of Korea. (2001). Images of Korean Culture, Seoul: The national folk museum of Korea

Tsui, C. (2013). From symbols to spirit: Changing conceptions of national identity in Chinese fashion. Fashion Theory, 17(5), 579-604.

\section{Copyrights}

Copyright for this article is retained by the author(s), with first publication rights granted to the journal.

This is an open-access article distributed under the terms and conditions of the Creative Commons Attribution license (http://creativecommons.org/licenses/by/4.0/). 